\title{
Isolation and Identification of Bacteria from Cell Phones of Health Care Workers from Central India
}

\section{Anupam Kakade ${ }^{1}$, Nandkishor Bankar ${ }^{2}$, Mangesh Padmawar ${ }^{1}$, Dhruba Hari Chandi ${ }^{2}$, Brij Raj Singh ${ }^{3}$, Dilip Gode ${ }^{4}$}

'Assistant Professor, Department of Surgery, DMMC, Wanadongri Nagpur; 'Assistant Professor, Department of Microbiology, JNMC, DMIMS, Wardha; ${ }^{3}$ Professor,Department of Anatomy, DMMC, Wanadongri Nagpur; ${ }^{4}$ Dean \& Professor DMMC, Wanadongri Nagpur

\section{ABSTRACT}

Introduction: The telecommunications market in India is currently the second-largest in the world. Cell phones have been shown to pose a health threat with tens of thousands of microbes residing on every square inch of the phone. It has been observed that pathogenic bacteria exist on around 40 percent of patient-related cell phones and about 20 percent of hospital staff-related mobile phones. Cell phones are difficult to clean and therefore have the potential for contamination with multiple bacterial agents. Doctors and health care workers (HCW) serving in intensive care units (ICUs) or operating units are widely exposed to deadly micro-organisms. HCWs often become carriers and may act as vectors and spread microorganisms wherever they are taken.

Material And Method: A total of $60 \mathrm{HCW}$ cell phones were tested for their bacterial contamination at Datta Meghe University of Medical Sciences. Consent was obtained from all persons whose mobile phones had been included in this study. Swabs were soaked in the tube containing peptone water. The cell phones analyzed were obtained at random from four departments: laboratory, Surgical Intensive Care Unit, surgical unit, and Operation theater T area. The specimen was obtained using a sterile cotton swab moistened with sterile peptone water. After 24 hours of incubation, plates were examined for the growth of microbial colonies.

Results: A total of 60 mobile phones were included and samples were collected. This study enrolled the mobile phones of 15 (25\%) nurses, 15 (25\%) Doctors, 15 (25\%) attendent, and $15(25 \%)$ laboratory technicians. All cellphones were touch screens having back cover. Coagulase negative Staphylococci (CoNS) was isolated from 24 (40\%) cellphones. Methicillin sensitive Staphylococcus aureus (MSSA) and Methicillin resistant Staphylococcus aureus (MRSA) were isolated from 21 (35\%) and 15 $(25 \%)$ cells respectively. Isolation of Diphtheroids, Coagulase negative Staphylococci (CoNS), Pseudomonas aeruginosa, Esherichia coli, Micrococci, Acinetobacter species and ESBL Klebsiella was 18(30\%), 24(40.0\%), 22 (36.6\%), 7(11.7\%), 11(18.3\%), $5(8.3 \%)$, and $3(5.0 \%)$ respectively.

Conclusion: Mobile phones can serve as a potential carrier for the nosocomial infection spread. Therefore regular screening of mobile phones, proper sterilization and hand hygiene is recommended for all health care workers.

Key Words: Cell phone, Mobile, HCW, Microbial contamination

\section{INTRODUCTION}

There is a tremendous increase in the use of cell phones in India. Now India has become $2^{\text {nd }}$ largest telecommunications market in the world. Due to cell phones, there is convenience in contact between people, either by calling, texting, or by email. Today, cell phones come up with a range of apps, internet browsing, e-mails, gaming, accessing social networking sites, music and video apps, radio, E-books, dictionary, etc. The majority of consumers are in the 15 to 25 age group ${ }^{1}$.

Regardless of the cell phone's accomplishments and advantages, it is easy to underestimate its health hazard; this is against the backdrop that many consumers can ignore personal hygiene, and the number of people who may be using the same cell-phone. Continuous cellphone handling by users exposes it to a range of microorganisms, rendering it a good carrier for organisms. Cell phones have been shown to pose a health threat with millions of microbes residing on every square inch of the phone ${ }^{2}$. It has been observed that pathogenic bacteria exist on around 40 percent of patientrelated cell phones and about 20 percent of hospital staffrelated mobile phones ${ }^{3}$. Constant handling of cell phones in hospitals (patients, their relatives, and health care workers, etc.) makes it an open breeding ground for the transmission

\section{Corresponding Author:}

Dr. Nandkishor Bankar, Assistant Professor, Department of Microbiology, JNMC, Wardha. E-mail: drbankarnj28@gmail.com

ISSN: 2231-2196 (Print)

Received: 13.05 .2020
ISSN: 0975-5241 (Online)

Revised: 05.06 .2020
Accepted: 14.06 .2020
Published: 21.07 .2020 
of micro-organisms, and healthcare associated infections $(\mathrm{HAI})^{4}$. The heat created by cell phones helps to harbor bacteria on the device at alarmingly highlevels ${ }^{5}$.

Cell phones are difficult to clean and therefore have the potential for contamination with multiple bacterial agents ${ }^{6}$. Doctors and HCW serving in intensive care units (ICU) or operation theaters are widely exposed to these pathogenic micro-organisms. HCWs often become carriers and may act as vectors and spread microorganisms wherever they are taken ${ }^{7}$. Colonized micro-organisms in health-care workers can be transmitted to patients, though patients do not have direct cell phone contact. Nosocomial infection can occur in patients with a weak immune system, but in patients with a strong immune system, microorganisms may not cause serious harm ${ }^{8}$.

The present study was therefore conducted with the goal of screening healthcare personnel's cell phones for the presence of microorganisms and to isolate and identify microorganisms on them.

\section{MATERIAL AND METHODS}

The present study was a cross-sectional study conducted in Datta Meghe Medical College, Nagpur in collaboration with Jawaharlal Nehru Medical College, Sawangi Meghe, Wardha (DMIMS) over a period of two months. A total of 60 $\mathrm{HCW}$ cell phones were identified and tested for their bacterial contamination at the Department of Microbiology. Consent was obtained from all persons whose mobile phones had been included in this study. Swabs were soaked in the tube containing peptone water.

The cell phones analyzed were obtained at random from four departments: laboratory, SICU, surgical unit, and OT area. The specimen was obtained using sterile cotton swab dipped insterile peptone water. The swab was rotated on the sides, back and over the screen of cell phones. All swabs were surface streaked immediately on the Blood agar and MacConkey agar. Inoculated blood and MacConkey's agar plates were quickly transferred to the microbiology laboratory along with the inoculated peptone water tubes. Blood and MacConkey agar plates were aerobically incubated at $37^{\circ} \mathrm{C}$ for 24 hours.

After 24 hours of incubation, plates were examined for growth of microbial colonies. Gram staining of all the isolates was performed for the identification of the bacteria. Isolated bacterial colonies were then identified according to the standard microbiological, biochemical methods 9 . On Mueller Hinton agar plates, Staphylococcus aureus and coagulase-negative staphylococci (CoNS) isolates were further verified by Kirby- Bauer disc diffusion method ${ }^{10}$ for their methicillin resistance using cefoxitin $(30 \mu \mathrm{g})$ disks.

Gram-negative bacteria were identified on the basis of their lactose and non-lactose fermenting colonies, gram stain, oxidase, catalase, triple sugar iron agar (TSI), methyl red, indole, citrate, Voges Proskauer, (IMViC) and urease tests. The extended spectrum beta-lactamase (ESBL) was tested by using the double disk diffusion process, as per the recommendation of CLSI. The discs used were ceftazidime 30 $\mu \mathrm{g}$, ceftazidime-clavulanate $30 / 10 \mu \mathrm{g}$, cefotaxime $30 \mu \mathrm{g}$, and cefotaxime-clavulanate 30/10 $\mu \mathrm{g}$. An increase of about $5 \mathrm{~mm}$ in zone diameter for either antimicrobial agent tested in combination with clavulanate vs. the zone diameter of the agent when tested alone was confirmed as ESBL producer ${ }^{11}$.

Using SPSS (version 16.0) software data were analyzed ${ }^{12}$, $\mathrm{P}$-value of $>0.05$ was used as the cut off value for statistical significance. For summarizing qualitative data counts and percentage were used. For normally distributed quantitative data Mean and standard deviation (SD) were used as measures of central tendency and dispersion, respectively.

\section{RESULTS}

A total of 60 mobile phones were included and samples were collected. This study enrolled the mobile phones of $15(25 \%)$ nurses, 15 (25\%) Doctors, 15 (25\%) attendant and 15 (25\%) laboratory technicians. All cellphones were touch screens having back cover.

\section{Table 1: Cell phone enrolled from different HCW}

\begin{tabular}{lcc} 
Cell phone enrolled & Number & $\%$ \\
Doctors & 15 & $25 \%$ \\
Nurses & 15 & $25 \%$ \\
Attendants & 15 & $25 \%$ \\
laboratory workers & 15 & $25 \%$ \\
\hline
\end{tabular}

Of the 15 doctors, mixed growth was observed in 10 $(66.67 \%)$ and single growth was seen $5(33.33 \%)$ cellphone. In nurses' cellphone, 9 (60\%) showed mixed growth and 4 (26.67\%) showed single growth. In 2 cases no growth was observed. 12 (80\%) attendants mobile showed mixed growth and $3(20 \%)$ showed single growth. In laboratory workers, cell phones mixed growth was observed in $13(86.67 \%)$ and single growth was seen in $2(13.33 \%)$. Overall out of 60 samples $44(73.33 \%)$ mixed growth, $14(23.33 \%)$ single growth, and $2(3.33 \%)$ no growth was observed. 
Table 2: Bacterial contamination in HCW

\begin{tabular}{llccccc} 
HCW & Mixed $(2$ or more organisms) & Single growth & No growth & Total & Mean & SD \\
Doctors & $10(66.67 \%)$ & $5(33.33 \%)$ & 0 & 15 & 2.27 & 1.0 \\
Nurses & $9(60 \%)$ & $4(26.67 \%)$ & $2(13.33 \%)$ & 15 & 2.00 & 1.26 \\
Attendants & $12(80 \%)$ & $3(20 \%)$ & 0 & 15 & 2.27 & 0.85 \\
laboratory workers & $13(86.67 \%)$ & $2(13.33 \%)$ & 0 & 15 & 2.60 & 0.88 \\
Total & $44(73.33 \%)$ & $14(23.33 \%)$ & $2(3.33 \%)$ & 60 & 2.28 & 0.46 \\
\hline
\end{tabular}

Table 3: Isolation of organisms

\begin{tabular}{lll} 
Organisms & $\begin{array}{l}\text { Number } \\
(\mathbf{n = 6 0})\end{array}$ & $\%$ \\
$\begin{array}{l}\text { Methicillin sensitive Staphylococcus } \\
\text { aureus }\end{array}$ & 21 & $35.0 \%$ \\
$\begin{array}{l}\text { Methicillin-resistant Staphylococcus } \\
\text { aureus (MRSA) }\end{array}$ & 15 & $25.0 \%$ \\
$\begin{array}{l}\text { Diphtheroids } \\
\text { Coagulase negative Staphylococci }\end{array}$ & 18 & $30.0 \%$ \\
(CoNS) & 24 & $40.0 \%$ \\
Pseudomonas aeruginosa & 22 & $36.7 \%$ \\
Escherichia coli & 7 & $11.7 \%$ \\
Micrococci & 11 & $18.3 \%$ \\
Acinetobacter species & 5 & $8.3 \%$ \\
ESBL Klebsiella & 3 & $5.0 \%$ \\
\hline
\end{tabular}

Coagulase negative Staphylococci (CoNS) was isolated from $24(40 \%)$ cellphones. Methicillin sensitive Staphylococcus aureus (MSSA) and Methicillin-resistant Staphylococcus aureus (MRSA) were isolated from21 (35\%) and 15 (25\%) cells respectively. Isolation of Diphtheroids, Coagulase negative Staphylococci (CoNS), Pseudomonas aeruginosa, Esherichia coli, Micrococci, Acinetobacter species and ESBL Klebsiella was 18(30\%), 24(40.0\%), 22 (36.6\%), 7(11.7\%), $11(18.3 \%), 5(8.3 \%)$, and 3(5.0\%) respectively.

\section{DISCUSSION}

Societies should adapt microbiological and hygiene practices for a healthy life. Constant mobile handling by multiple users exposes it to a range of organisms and also serves as a carrier for microbes. Mobile phones may pose a health hazard with millions of microbes living on every square inch of the cell phone ${ }^{2}$.

Staphylococci are commonly present on clothes, bed sheets, and other human environments. $S$ epidermidis is a common flora of human skin. S aureus exists in about $20-50 \%$ of human being a nasal carrier ${ }^{13}$.

In our study, it was observed that of the 15 doctors, mixed growth was observed in $10(66.67 \%)$ and single growth was seen $5(33.33 \%)$ cellphone. In nurses' cellphone, 9 $(60 \%)$ showed mixed growth and $4(26.67 \%)$ showed single growth. In 2 cases no growth was observed. $12(80 \%)$ attendants mobile showed mixed growth and $3(20 \%)$ showed single growth. In laboratory workers' cell phones mixed growth was observed in $13(86.67 \%)$ and single growth was seen in $2(13.33 \%)$. Overall out of 60 samples $44(73.33 \%)$ mixed growth, $14(23.33 \%)$ single growth, and $2(3.33 \%)$ no growth was observed.

Pseudomonas aeruginosa, Escherichia coli, and Klebsiella pneumoniae which cause hospital infections and can serve as a vector for the spread of nosocomial pathogens as reported by Karabay et al. They also observed that most of the isolated organisms were skin flora, $16.7 \%$ of the samples were positive for pathogens which were known to be associated with nosocomial infection, like Enterococci species, $S$. aureus and K. pneumonia but in contrast to our study Methicillin-Resistant $S$. aureus (MRSA) were not isolated ${ }^{14}$. Cell phone users are everywhere: in the community, in the workplace, in the hospitals, and in schools. Hence, they may be the cause of the community spread of the infection ${ }^{15}$. Jeske et al. also reported that in the operating theatre, bacterial contamination of the hands of anesthetists by personal cell phones (38/40 doctors, $4 / 40$ with human pathogenic bacteria) occurred ${ }^{16}$. Intensive care unit patients and patients with burns are very vulnerable to infectious diseases, thereby raising the risk of transmission of nosocomial infections in these cases through computer keyboards ${ }^{17}$. In a study by Singh P et al. 18 K. pneumoniae strains, isolated in Clinical Microbiology Laboratory should be tested phenotypically for ESBL production as it can pose a major threat to patient care and incidence of ESBL producing $K$. pneumoniae was detected and observed that $55(45.8 \%)$ strains were ESBL producers.

Pseudomonas aeruginosa is a metabolically active proteobacterium in terrestrial, marine, insect, human and plant-host environments which is responsible for nosocomial infections. In our study, it was isolated in $36.7 \%$ of the cellphones of the health care workers ${ }^{19}$.

MRSA and MSSA isolated in our study were $35.0 \%$ and $25 \%$, respectively. The principal reservoir of $S$. aureus is the hand and can be introduced in the food causing food poisoning as well as wound infections ${ }^{20}$. 
In our study, Escherichia coli and Klebsiella pneumoniae isolated were $11.7 \%$ and $5 \%$, respectively. Deotale et al. in their study observed the biofilm production for these organisms and found that they are multi drug resistant if they are isolated from the urine and produces biofilm ${ }^{21}$. In a study by Mudey G. and Munjal R., it was observed that nasal carriage of Staphylococcus aureus among undergraduate medical students $16 \%$ and the prevalence of MRSA and inducible clindamycin resistance was $5 \%$ and $3.5 \%{ }^{22}$.

\section{CONCLUSION}

Mobile phones of Heath care workers are highly contaminated with micro-organisms. These can serve as a potential carrier for the nosocomial infection spread. Therefore regular screening of mobile phones, proper sterilization, and hand hygiene is recommended for all health care workers. Also, care should be taken while handling the mobile in health care settings so that transmission of infection can be reduced.

Acknowledgement: Authors acknowledge the immense help received from management of Datta Meghe Institute of Medical Sciences, Sawangi, India for providing support to conduct this study.

\section{Conflicts of Interest: Nil}

\section{Source of Funding: Nil}

\section{REFERENCES}

1. Alpana Vaidya, Vinayak Pathak, Ajay Vaidya. Mobile Phone Usage among Youth. International journal of applied research and studies. 2016: 5(3): 1-16. https://doi.org/10.20908/ijars. v5i3.9483

2. Ekrakene T, Igeleke CL. Micro-organisms associated with public mobile phones along Benin-sapele Express Way, Benin City, Edo State of Nigeria. J Appl Sci Res. 2007;3:2009-12.

3. D.N. Tagoe, Gyande Vik, Ansah Evo., (2011), Bacterial contaminant of mobile phones, Central microbiology journal, 65, pp 121-125.

4. Tagoe DN, Gyande VK, Ansah EO. Bacterial Contamination of Mobile Phones: When Your Mobile Phone Could Transmit More Than Just a Call. Webmed Central Microbiology. 2011;2(10):WMC002294.

5. Singh A, Purohit B. Mobile phones in hospital settings: a serious threat to infection. Occup Health Saf. 2012 Mar; 81(3):42-4.

6. Brady RR, Wasson A, Stirling I, McAllister C, Damani NN. Is your phone bugged? The incidence of bacteria known to cause nosocomial infection on healthcare workers' mobile phones. J Hosp Infect. 2006 Jan; 62(1):123-5.
7. Kokate SB, More SR, Gujar V, Mundhe S, Zahiruddin QS. Microbiological flora of mobile phones of resident doctors. J Biomed Sci Eng. 2012;5:696-698.

8. Killic, I.H., Ozaslan, M., Karagoz, I.D., Zer, Y. and Davatoglu, V. (2009) The microbial contamination of mobile phones used by healthcare staff. Pakistan Journal of Biological Sciences, 12, 882-884.

9. Ainsworth GC, Sparow FK, Sussman AS. The Fungi, Volume IVA, Taxononomic Review with Keys: Ascomycetes and Fungi Imperfecti. New York and London: Academic Press; 1973.

10. Bauer AW, Kirby WM, Sherris JC, Turck M. S., Antibiotic susceptibility testing by a standardized single disk method. Am J Clin Pathol. 1966 Apr; 45(4):493-6.

11. Wayne, PA, Clinical and Laboratory Standards Institute. Performance standards for antimicrobial susceptibility testing; Twenty-fourth informational supplement, M100-S24. : CLSI; 2014.

12. Daniel WW. Biostatistics: A foundation for analysis in the health sciences. 9th ed. Hoboken, NJ: Wiley; 2009.

13. Melnick J, Edward A. Medical Microbiology. 23th ed. New York: McGraw-Hill Professional; 2004.

14. Karabay O, Kocoglu E, Tahtaci M. The role of mobile phones in the spread of bacteria associated with nosocomial infections. J Infect Dev Ctries. 2007;1:72-3.

15. Brady RR, Fraser SF, Dunlop MG, Paterson-Brown S, Gibb APBacterial contamination of mobile communication devices in the operative environment. J Hosp Infect. 2007 Aug; 66(4):397-8.

16. Jeske HC, Tiefenthaler W, Hohlrieder M, Hinterberger G, Benzer A. Bacterial contamination of anaesthetists' hands by personal mobile phone and fixed phone use in the operating theatre. Anaesthesia. 2007 Sep; 62(9):904-6.

17. Neely AN, Maley MP, Warden GD. Computer keyboards as reservoirs for Acinetobacter baumannii in a burn hospital. Clin Infect Dis. 1999 Nov; 29(5):1358-60.

18. Singh P, Basak S. Extended spectrum $\beta$-Lactamases producing Klebsiella pneumoniae: A threat to patient care. J Datta Meghe Inst Med Sci Univ 2017;12:234-7.

19. Ramos JL, editor. Pseudomonas. New York: Kluwer Academic/ Plenum Publishers; 2004. p. 2132.

20. Bankar, N., Wankhade, A., Bramhane, R. B., Hathiwala, R., \& Chandi, D. H. (2018). Bacteriological Profile of PUS / WOUND SWAB Andantimicrobial Susceptibility of Staphylococcus Aureus Isolated from of PUS \& WOUND SWAB of Indoor Patients of Tertiary Care Hospital in Durg, Chhattisgarh India. International Journal of Innovative Research in Medical Science, 3(04), 1976 to 1980. https://doi.org/10.23958/ijirms/vol03-i04/12

21. Deotale VS, Attal R, Joshi S, Bankar N. Correlation between biofilm formation and highly drug resistant uropathogens (HDRU). Int J Curr Res Rev. 2015;7(2):61.

22. Munjal, R., Mudey, G.Nasal carriage of Staphylococcus aureus among undergraduate medical students: Prevalence and antibiogram including methicillin resistance, inducible clindamycin resistance, and high-level mupirocin Resistance Journal of Datta Meghe Institute of Medical Sciences University: 2018;13(2), 91-94. 